\title{
TEPUNG REBUNG TERMODIFIKASI SEBAGAI SUBSTITUEN TERIGU PADA PEMBUATAN DONAT KAYA SERAT
}

\section{MODIFIED BAMBOO SHOOTS FLOUR AS WHEAT SUBSTITUENT IN FIBER RICH DONUT MAKING}

\author{
Meta Haryani ${ }^{1}$, Lina Widawati ${ }^{2}$, Eva Ramalia Sari ${ }^{3}$ \\ 1) Program Studi Teknologi Pertanian Fakultas Pertanian UNIVED \\ 2) Program Studi Teknologi Pangan Fakultas Pertanian UNIVED \\ 3) Program Studi Agribisnis Fakultas Pertanian UNIVED
}

\begin{abstract}
ABSTRAK
Rebung adalah tunas muda yang tumbuh dari akar bambu. Selain digunakan sebagai isi lumpia, rebung juga sering digunakan sebagai bahan sayur untuk masakan khas Jawa Tengah. Tujuan penelitian yaitu untuk mengkarakterisasi sifat donat kaya serat yang dibuat dari tepung rebung termodifikasi. Penelitian diawali dengan pengolahan tepung rebung termodifikasi dengan variasi perlakuan waktu fermentasi, yaitu 3 hari dan 5 hari. Tahap selanjutnya adalah pengolahan donat dengan substitusi tepung rebung termodifikasi dengan perlakuan perbandingan tepung terigu dan tepung rebung sebanyak $400: 100 \mathrm{gr}$, $300: 200$ gr dan $200: 300$ gr. Analisis yang dilakukan adalah analisis kadar abu dan analisis tingkat kesukaan panelis untuk parameter warna, rasa dan tekstur. Hasil pengukuran kadar abu menunjukkan bahwa tidak ada perbedaan yang nyata pada perlakuan fermentasi 3 hari, sedangtkan pada perlakuan waktu fermentasi 5 hari, diperoleh hasil bahwa semakin banyak tepung rebung termodifikasi yang digunakan, maka kadar abu donat semakin besar. Uji kesukaan pada donat menunjukkan bahwa panelis lebih menyukai perlakuan perbandingan tepung terigu dan tepung rebung sebanyak $400: 100 \mathrm{gr}$ dan 300 : $200 \mathrm{gr}$ dan fermentasi selama 3 hari.
\end{abstract}

Kata kunci: rebung, tepung rebung termodifikasi, donat

\section{ABSTRACT}

Bamboo shoots are the young shoots that grow from the roots of bamboo. Besides being used as the contents of spring rolls, bamboo shoots are also frequently used as a vegetable for the Central Javanese cuisine. The purpose of this study was to characterize the properties of fiber-rich donut made from modified bamboo shoots flour. The study begins with a modified bamboo shoots processing with treatment variations of fermentation time, which is 3 days and 5 days. The next stage is the processing of modified bamboo shoots donuts substitution with treatment comparisons of flour and bamboo shoots as much as $400: 100$ grams, $300: 200 \mathrm{gr}$ and $200: 300 \mathrm{gr}$. Analysis is conducted for ash content analysis and analysis of the level of preference parameters panelists for color, flavor and texture. Ash content measurement results showed that there was no significant difference in treatment 3 days of fermentation, where as the fermentation time at 5 days of treatment, the results showed that the more flour modified bamboo shoots flour are used, the greater the ash content donuts. A test showed that the donut panelists favored treatment comparison flour and bamboo shoots as much as $400: 100 \mathrm{gr}$ and $300: 200 \mathrm{gr}$ and ferment for 3 days.

Keywords: bamboo shoots, modified bamboo shoots flour, doughnut 


\section{PENDAHULUAN}

Ketahanan pangan mempunyai peranan penting khususnya negara-negara berkembang dari sudut pandang biologi, ekonomi, maupun segi polotik. Menurut FAO ada 4 komponen yang harus dipenuhi untuk mencapai ketahanan pangan yaitu kecukupan ketersedian pangan, stabilitas ketersedian pangan tanpa fluktuasi dari musim ke musim atau dari tahun ketahun, aksesibilitas atau keterjangkauan terhadap pangan serta kualitas atau keamanan pangan. Salah satu solusi dalam memenuhi ketahanan pangan ini adalah melalui diversifikasi pangan lokal. Kegiatan diversifikasi pangan merupakan pemanfaatan pangan lokal asalnya atau pemanfaatan pangan lokal. Komoditi lokal diproses untuk meningkatkan nilai ekonomis pangan tersebut sekaligus peningktan pendapatan ekonomi masyarakat pengelolanya. Selain itu, permintaan terhadap produk makanan kesehatan seperti bebas gula, makanan rendah kalori dan makanan kaya serat meningkat dengan pesat. Berbagai sumber bahan berserat tinggi seperti selulosa, hemiselulosa, lignin dan gum sekarang pengembangan produk makanan tersebut (Chandalia,M et al, 2000).
Salah satu pangan lokal yang berpotensi untuk diolah menjadi tepung yaitu rebung. Rebung adalah tunas muda dari pohon bambu yang tumbuh dari akar pohon bambu. Penduduk Indonesia biasanya memanfaatkan rebung sebagai makanan yaitu sebagai sayur. Rebung mengandung protein 2,6 g, karbohidrat $5,2 \mathrm{~g}$, serat 2,2 $\mathrm{g}$ dan lemak $0,3 \mathrm{~g}$ (Anonim,2009). Selain itu, rebung mengandung vitamin, mineral dan 12 asam amino ensensial yang sangat dibutuhkan oleh tubuh. Rebung berpotensi diolah menjadi aneka macam olahan pangan dan tepung. Meskipun kadar karbohidratnya relatif rendah dan mengandung serat (Muchtadi, 2001). Rebung mempunyai kadar air yang tinggi sementara kandungan karbohidratnya rendah $(5,2 \mathrm{~g} / 100 \mathrm{~g})$ selain itu rebung mempunyai kandungan serat yang tinggi dan menyulitkan untuk dibuat tepung secara langsung, maka perlu pengolahan dengan cara fermentasi. Menurut Balai Besar Teknologi Pati (2011), proses modifikasi bertujuan untuk menghasilkan tepung dengan nilai gizi serta karakteristik fisiko-kimia dan organoleptik. Tepung ini memiliki viskositas (maksimal) yang relatif rendah (255 BU) bila dibandingkan dengan viskositas maksimal tapioka (1200 BU). 
Berdasarkan latar belakang diatas maka penulis tertarik untuk meneliti teknologi pengolahan tepung rebung termodifikasi sebagai substitusi tepung terigu pada pembuatan roti donat kaya serat, khususnya terhadap tingkat kesukaan konsumen.

Penelitian ini bertujuan untuk mengetahui tingkat kesukaan konsumen terhadap pengolahan tepung rebung termodifikasi sebagai substitusi tepung terigu pada pembuatan roti donat dengan metode fermentasi berdasarkan parameter warna, aroma, rasa dan tekstur.

\section{METODE PENELITIAN}

\section{Bahan dan Alat}

Bahan yang digunakan dalam penelitian pengolahan tepung rebung adalah rebung betung. Rebung diperoleh dari Kelurahan Talang Datuk Kabupaten Seluma Kecamatan Seluma. Bahan yang digunakan untuk pembuatan donat adalah tepung terigu dan tepung rebung, mentega , susu bubuk, gula pasir, parmipan, garam, 2 butir telur, air dan minyak goreng, dan gula halus. Adapun alat-alat yang digunakan dalam pengolahan tepung rebung yaitu pisau, baskom, timbangan, blender, wajan, sendok, tirisan, dan saringan.

\section{Metode}

Penelitian ini terdiri dari tahap pendahuluan dengan menyiapkan bahan dasar pembuatan tepung rebung dan proses pengolahan tepung rebung dengan variasi waktu fermentasi (3 dan 5 hari) dan tahap utama yaitu proses pengolahan roti donat dengan tepung rebung sebagai substitusi tepung terigu. Analisis yang dilakukan adalah analisis kadar abu dan uji organoleptik menggunakan panelis agak terlatih sebanyak 20 orang.

\section{HASIL DAN PEMBAHASAN}

\section{Kadar Abu}

Kadar abu dalam bahan pangan adalah hasil pembakaran garam-garam mineral. Dalam proses pembakaran, bahan-bahan organiknya terbakar, tetapi tidak zat-zat anorganiknya, sehingga disebut sebagai abu (Winarno, 2004). Analisis kadar abu yang dilakukan pada roti donat menunjukkan hasil 1,80\% hingga 4,85\% dimana pada perlakuan perbandingan tepung terigu dan tepung rebung sebanyak 400 gr : 100 gr menunjukkan kandungan kadar abu terkecil yaitu $1,80 \%$ sedangkan pada perlakuan perbandingan tepung terigu dan tepung rebung 200 gr : 300 gr menunjukkan kandungan kadar abu tertinggi yaitu 4,85\%. Menurut SNI No. 01-3840-1995 roti tawar yang mensyaratkan kandungan maksimum abu hanya 3\% (BSN, 1995). Hasil pengujian kadar abu pada roti donat dapat dilihat pada Tabel 1 sebagai berikut: 
Tabel 1. Hasil Pengujian Kadar Abu Roti Donat

\begin{tabular}{ccc}
\hline Perbandingan Tepung & \multicolumn{2}{c}{ Waktu Fermentasi } \\
\cline { 2 - 3 } Tepung Terigu : Tepung Rebung & 3 Hari & 5 Hari \\
\hline $400: 100 \mathrm{gr}$ & $4,34 \mathrm{a}$ & $1,80 \mathrm{a}$ \\
$300: 200 \mathrm{gr}$ & $4,47 \mathrm{a}$ & $2,29 \mathrm{a}$ \\
$200: 300 \mathrm{gr}$ & $4,85 \mathrm{a}$ & $4,46 \mathrm{~b}$
\end{tabular}

Ket : : angka yang diikuti oleh kode huruf yang berbeda menunjukkan adanya perbedaan yang nyata pada taraf signifikansi $5 \%$.

Dapat dilihat bahwa pada perlakuan hidup sehat, maka tuntutan konsumen waktu fermentasi 5 hari dengan terhadap bahan pangan yang mempunyai perbandingan tepung terigu dan tepung rebung sebanyak 400 gr : 100 gr komposisi gizi yang baik memiliki penampakan dan cita rasa yang menarik menunjukkan kandungan kadar abu yaitu $1,80 \%$ dan pada perlakuan perbandingan tepung terigu dan tepung rebung $300 \mathrm{gr}$ : 200 gr menunjukan kandungan kadar abu yaitu 2,29\%. Tingginya kadar abu pada roti donat kaya serat disebabkan oleh tingginya kandungan mineral pada rebung (Subagio. A, 2007).

Perlakuan waktu fermentasi 5 hari dengan perbandingan tepung terigu dan tepung rebung sebanyak $400 \mathrm{gr}$ : $100 \mathrm{gr}$ menunjukkan kandungan kadar abu yaitu $1,80 \%$ dan pada perlakuan perbandingan tepung terigu dan tepung rebung $300 \mathrm{gr}$ : 200 gr menunjukan kandungan kadar abu yaitu 2,29\%. Tingginya kadar abu pada roti donat kaya serat disebabkan oleh tingginya kandungan mineral pada rebung.

Seiring dengan semakin meningkatnya serta memiliki fungsi fisiologis tertentu bagi tubuh, juga semakin meningkat (Hasyim dan Yusuf, 2009; Nindyarani, dkk, 2011).

\section{Sifat Organoleptik}

\section{Warna}

Warna adalah suatu kriteria organoleptik yang berhubungan dengan indra penglihatan yaitu mata dari segi fisiopsikologis. Warna adalah respon mata manusia terhadap rangsangan sinar. Mata hanya peka terhadap sinar dengan panjang gelombang berkisar antara 380770 nm (Rampengan, dkk, 1981). Berdasarkan hasil dari uji tingkat kesukaan pada roti donat yang diujikan terhadap 20 panelis berdasarkan parameter warna diperoleh nilai rerata tingkat kesukaan konsumen sebagai berikut:

kesadaran masyarakat akan pentingnya

Tabel. 2. Hasil Rerata Uji Kesukaan Warna Roti Donat 


\begin{tabular}{ccc}
\hline Perbandingan Tepung & \multicolumn{2}{c}{ Waktu Fermentasi } \\
\cline { 2 - 3 } Tepung Terigu : Tepung Rebung & 3 Hari & 5 Hari \\
\hline $400: 100 \mathrm{gr}$ & $1.65 \mathrm{a}$ & $1.95 \mathrm{a}$ \\
$300: 200 \mathrm{gr}$ & $2.45 \mathrm{~b}$ & $2.30 \mathrm{~b}$ \\
$200: 300 \mathrm{gr}$ & $3.45 \mathrm{c}$ & $3.25 \mathrm{c}$ \\
\hline
\end{tabular}

Ket:

Angka yang diikuti huruf yang sama menunjukkan tidak berbeda nyata .Pada taraf $\alpha 5 \%$ (berlaku pada kolom yang sama)

Atribut mutu = 1 ( sangat suka),2(suka),3(agak suka),4(tidak suka), 5 (sangat tidak suka)

Diketahui bahwa hasil uji kesukaan terhadap warna roti donat, sampel yang memiliki skor penilaian terendah adalah perlakuan 400gr : 100gr dengan perlakuan fermentasi 3 hari. yang memiliki skor penilaian 1,65 yang terletak pada skala penerimaan sangat suka sedangkan sampel yang memiliki penilaian tertinggi adalah pada perlakuan 200gr : 300gr dengan perlakuan fermentasi 3 hari dengan skor penerimaan 3,45 yang terletak pada skala penerimaan agak suka. Hasil uji lanjutan BNT menunjukkan bahwa perlakuan 200gr :300gr dengan perlakuan 3 hari tidak berbeda nyata dengan perlakuna 400gr : 100gr, 300gr : 200gr berbeda nyata dengan 300gr : 200gr dan 200gr : $300 \mathrm{gr}$.
Penilaian tingkat kesukaan konsumen dengan parameter warna, panelis lebih menyukai perlakuan dengan perbandingan tepung terigu dan tepung rebung sebanyak 300 gr : 200 gr dengan waktu fermentasi selama 3 hari, dimana warna yang dihasikan warna kuning kecoklatan sesuai dengan warna roti donat, sehingga menarik perhatian konsumen.

\section{Rasa}

Berdasarkan hasil dari uji tingkat kesukaan pada roti donat yang diujikan terhadap 20 panelis berdasarkan parameter rasa diperoleh nilai rerata tingkat kesukaan konsumen sebagai berikut:

Tabel 3. Hasil Rerata Uji Kesukaan Rasa Roti Donat

\begin{tabular}{ccc}
\hline Perbandingan Tepung & \multicolumn{2}{c}{ Waktu Fermentasi } \\
\cline { 2 - 2 } Tepung Terigu : Tepung \\
Rebung
\end{tabular}




\begin{tabular}{ccc}
\hline $400: 100 \mathrm{gr}$ & $1.7 \mathrm{a}$ & $1.90 \mathrm{a}$ \\
$300: 200 \mathrm{gr}$ & $2.35 \mathrm{~b}$ & $2.45 \mathrm{~b}$ \\
$200: 300 \mathrm{gr}$ & $3.2 \mathrm{c}$ & $3.35 \mathrm{c}$ \\
\hline
\end{tabular}

Ket :

Angka yang diikuti huruf yang sama menunjukkan tidak berbeda nyata. Pada taraf $\alpha$ $5 \%$ (berlaku pada kolom yang sama)

Atribut mutu = 1 ( sangat suka),2(suka),3(agak suka),4(tidak suka), 5 (sangat tidak suka

Hasil uji tingkat kesukaan konsumen terhadap rasa roti donat, sampel yang memiliki penilaian terendar dari panelis yaitu pada perlakuan 400gr:100gr dengan perlakuan fermentasi 3 hari yang mendapatkan skor 1,7 terletak pada skala penerimaan sangat suka. Sedangkan penilaian skor tertinggi pada perlakuan 200 gr : 300 gr dengan penilaian 3.35 yang terletak pada skala agak suka.

Penilaian tingkat kesukaan rasa roti donat panelis lebih menyukai perlakuan 400gr :100gr fermentasi 5 hari dan 400gr:100gr fermentasi 3 hari dengan perbandingan tepung terigu dan tepung rebung sebanyak 400 gr : 100 gr dengan fermentasi 5 hari dan 3 hari. Pada perlakuan $400 \mathrm{~g}$ r: $100 \mathrm{gr}$ fermentasi 5 hari dan 400gr:100gr fermentasi 3 hari menimbulkan rasa yang khas roti donat sedangkan pada perlakuan 200g : 300gr fermentasi 5 hari dengan perbandingan tepung terigu dan tepung rebung sebanyak 200 gr : 300 gr menimbulkan rasa tepung rebung yang lebih dominan dengan serat yang lebih banyak dan rasa asam yang di timbulkan tepung rebung yang diproses secara fermentasi (Soekarto, 1985).

\section{Aroma}

Aroma dihasilkan dari senyawa-senyawa volatil yang terdapat pada bahan. Aroma dapat bertambah atau berkurang secara alami maupun karena proses pengolahan, seperti penggorengan, pengovenan atau proses lainnya (Salunkhe, 2000). Berdasarkan hasil dari uji tinggkat kesukaan pada roti donat yang diujikan terhadap 20 panelis berdasarkan parameter aroma diperoleh nilai rerata tingkat kesukaan konsumen disajikan pada Tabel 4. Hasil uji tingkat kesukaan konsumen terhadap roti donat, sampel yang memiliki skor penilaian terendah yaitu pada perlakuan 300gr:200gr dengan perlakuan fermentasi 3 hari yang memiiliki penilaian 2.4 dengan skala penerimaan

suka.

\section{Tabel 4. Hasil Rerata Uji Kesukaan Aroma Roti Donat}

\begin{tabular}{ccc}
\hline Perbandingan Tepung & \multicolumn{2}{c}{ Waktu Fermentasi } \\
\cline { 2 - 2 } Tepung Terigu : Tepung \\
Rebung
\end{tabular}




\begin{tabular}{ccc}
\hline $400: 100 \mathrm{gr}$ & $2.15 \mathrm{a}$ & $2.30 \mathrm{a}$ \\
$300: 200 \mathrm{gr}$ & $2.4 \mathrm{a}$ & $2.80 \mathrm{a}$ \\
$200: 300 \mathrm{gr}$ & $2.85 \mathrm{a}$ & $3.15 \mathrm{~b}$ \\
\hline
\end{tabular}

Ket :

Angka yang diikuti huruf yang sama menunjukkan tidak berbeda nyata .Pada taraf $\alpha$ $5 \%$ (berlaku pada kolom yang sama)

Atribut mutu = 1 (sangat suka),2(suka),3(agak suka),4(tidak suka), 5 (sangat tidak suka)

Sampel yang memiliki penilaian tertinggi yaitu pada perlakuan 200gr:300gr dengan fermentasi 5 hari dengan skor penilaian 3.15 dengan skala penerimaan agak suka. Penilaian tingkat kesukaan konsumen, dengan parameter aroma maka panelis lebih menyukai perlakuan dengan perbandingan tepung terigu dan tepung rebung sebanyak 300 gr : 200 gr dengan waktu fermentasi selama 3 hari menimbulkan aroma dengan khas roti donat . Sedangkan pada perlakuan dengan perbandingan tepung terigu dan tepung rebung sebanyak $300 \mathrm{gr}: 200 \mathrm{gr}$ dengan waktu fermentasi 5 hari menimbulakan aroma asam dari tepung rebung.

\section{Tekstur}

Berdasarkan hasil dari uji tinggkat kesukaan pada roti donat yang diujikan terhadap 20 panelis berdasarkan parameter tekstur diperoleh nilai rerata tingkat kesukaan konsumen sebagai berikut:

Tabel 5. Hasil Rerata Uji Kesukaan tekstur Roti Donat

\begin{tabular}{ccc}
\hline Perbandingan Tepung & \multicolumn{2}{c}{ Waktu Fermentasi } \\
\cline { 2 - 3 } Tepung Terigu : Tepung Rebung & 3 Hari & 5 Hari \\
\hline $400: 100 \mathrm{gr}$ & $2.05 \mathrm{a}$ & $2.20 \mathrm{a}$ \\
$300: 200 \mathrm{gr}$ & $2.75 \mathrm{a}$ & $2.30 \mathrm{a}$ \\
$200: 300 \mathrm{gr}$ & $2.9 \mathrm{a}$ & $3.00 \mathrm{~b}$ \\
\hline
\end{tabular}

Ket:
Angka yang diikuti huruf yang sama menunjukkan tidak berbeda nyata .Pada taraf $\alpha$
$5 \%$ (berlaku pada kolom yang sama)
Atribut mutu = 1 (sangat suka),2(suka),3(agak suka),4(tidak suka), 5 (sangat tidak suka)

Hasil uji tingkat kesukaan konsumen terhadap tekstur roti donat, sampel yang memiliki skor penilaian terendah yaitu pada perlakuan 400 gr : 100 gr dengan skor penilain 2.05 (suka) terdapat skala penerimaan suka. Sedangkan perlakuan yang mendapatkan penilaian tertinggi yaitu pada perlakuan 200 gr : 300 gr 
dengan skor penilaian 3.00 (agak suka) terdapat pada skala penerimaan agak suka, sehingga pada penilaian tingkat kesukaan konsumen terhadap tekstur roti donat, panelis lebih menyukai perlakuan 400 gr : 100 gr dengan perbandingan tepung terigu dan tepung rebung sebanyak 400 gr : 100 gr yang memiliki tekstur yang lembut sesuai dengan tekstur roti donat. Sedangkan pada perlakuan 200 gr : 300 gr dengan perbandinga tepung rebung sebanyak 200 gr dan 300 gr memiliki tekstur yang keras dengan serat dari rebung yang lebih dominan sehingga roti donat tidak mengembang.

\section{SIMPULAN}

Berdasarkan parameter warna konsumen lebih menyukai roti donat dengan perlakuan 400 gr : 100 gr dimana perbandingan tepung terigu dan tebung rebung sebanyak 400 gr :100 gr waktu fermentasi selama 3 hari dengan penilaian 1,65 (sangat suka). Berdasarkan parameter rasa konsumen lebih menyukai roti donat dengan perlakuan 400gr:100gr dimana perbandingan tepung terigu dan tebung rebung sebanyak 400 gr :100 gr waktu fermentasi selama 3 hari dengan penilaian 1,7(sangat suka). Berdasarkan parameter aroma konsumen lebih menyukai roti donat dengan perlakuan 300gr:200gr dimana perbandingan tepung terigu dan tebung rebung sebanyak 300 gr :200 gr waktu fermentasi selama 3 hari dengan penilaian 2,4 (suka). Berdasarkan parameter tekstur konsumen lebih menyukai roti donat dengan perlakuan 400 gr : 100 gr dimana perbandingan tepung terigu dan tebung rebung sebanyak 400 gr :100 gr waktu fermentasi selama 3 hari dengan penilaian 2,05 (suka).

\section{DAFTAR PUSTAKA}

Balai besar teknologi pati (2011), Pengkajian dan Pengembangan Teknologi Produksi Tepung Sorgum Termodifikasi. BPPT. Jakarta.

Anonim. 2009. Khasiat Rebung. http://masenchipz.com/khasiatrebung diakses pada 13 Mei 2010

Badan Standardisasi Nasional. 1995. Mutu dan Cara Uji Roti Tawar (SNI No. 01- 3840-1995). Badan Standardisasi Nasional. Jakarta.

Chandalia, M., A. Garg, D. Lutjohann, K. Bergmann, S.M. Grundy, dan L.J. Brinkley. 2000. Beneficial Effects of High Dietary Fiber Intake in patients eith Type 2 Diabetes Mellitus.

http://content.nejm.org/cgi/content/ full/342/19/1392. [20 November 2007]

Muchtadi, D. 2001. Sayuran sebagai sumber serat pangan untuk mencegah penyakit degeneratif. Jurnal Teknologi dan Industri Pangan. 12:61-71.

Salunkhe. 2000. Handbook of Food Analysis. Marcel Dekker Inc. New York.

Subagio A.2007.Industrialisasi Modified Cassava Flour (MOCAF) sebagai Bahan Baku Industri Pangan untuk Menunjang Diversifikasi PanganPokok 
Nasional Jember : Fakultas

Teknologi Pertanian,

UniversitasJember

Soekarto, ST. 1985. Penilaian

Organoleptik Untuk Industri

Pangan dan Hasil Pertanian.

Bharata Karya Aksara. Jakarta

Hasyim, A dan Yusuf, M. 2009. Ubi Jalar

Kaya Antosianin Pilihan Pangan

Sehat.

http://pangan.litbang.deptan.go.id.

Diakses tanggal 03 Juli 2010.
Nindyarani, AK., Sutardi, Suparmo. 2011. Karakteristik Kimia, Fisik dan Inderawi Tepung Ubi Jalar Ungu (Ipomea batatas Poiret) dan Produk Olahannya. Agritech vol. 31 (4).

Rampengan, V., Pontoh,J., Sember, DT. 1981. Dasar-dasar Pengawetan Makanan. Badan Kerjasama Perguruan Tinggi Negeri. Universitas Hasanuddin. Makassar.

Winarno, F. G. 2004. Kimia Pangan dan Gizi. Gramedia Pustaka Utama 